\title{
First report of Anisakis sp. (Nematoda: Anisakidae) parasitizing Muscovy duck in Marajó Island, state of Pará, Brazil
}

\author{
Primeiro relato de Anisakis sp. (Nematoda: Anisakidae) parasitando pato \\ doméstico na llha de Marajó, estado do Pará, Brasil
}

\begin{abstract}
Elaine Lopes de Carvalho1,2 (1); Ricardo Luis Sousa Santana² (D); Evonnildo Costa Gonçalves ${ }^{3}$ (D);
\end{abstract}
Raul Henrique da Silva Pinheiro ${ }^{2,4}$ (i); Elane Guerreiro Giese ${ }^{1,2^{*}}$ (D)

\begin{abstract}
1 Programa de Pós-graduação em Saúde e Produção Animal na Amazônia, Instituto da Saúde e Produção Animal, Universidade Federal Rural da Amazônia - UFRA, Belém, PA, Brasil

${ }^{2}$ Laboratório de Histologia e Embriologia Animal, Instituto da Saúde e Produção Animal, Universidade Federal Rural da Amazônia UFRA, Belém, PA, Brasil

${ }^{3}$ Laboratório de Tecnologia Biomolecular, Instituto de Ciências Biológicas, Universidade Federal do Pará - UFPA, Belém, PA, Brasil ${ }^{4}$ Programa de Pós-graduação em Sociedade, Natureza e Desenvolvimento, Instituto de Ciências e Tecnologia das Águas, Universidade Federal do Oeste do Pará - UFOPA, Santarém, PA, Brasil
\end{abstract}

\begin{abstract}
How to cite: Carvalho EL, Santana RLS, Gonçalves EC, Pinheiro RHS, Giese EG. First report of Anisakis sp. (Nematoda: Anisakidae) parasitizing Muscovy duck in Marajó Island, state of Pará, Brazil. Braz J Vet Parasito/ 2020; 29(2): e020319. https://doi.org/10.1590/ S1984-29612020015
\end{abstract}

\begin{abstract}
Among the avian used for human consumption, the Muscovy duck is well adapted to various climatic conditions and its breeding is widespread due to its easy handling, and its meat is widely consumed and appreciated, especially in the cuisine of northern Brazil. The present study aimed to report and identify taxonomically the nematodes found in the esophagus of Muscovy ducks reared and marketed in the municipality of Soure, Marajó Island, state of Pará, Brazil, and discuss its zoonotic potential to human. The samples consisted of 30 specimens of Cairina moschata domestica analyzed. A total of 258 nematodes were recovered, which were strongly fixed in the esophageal mucosa of hosts. The morphological and morphometric characteristics were compatible with Anisakis third-stage larvae.
\end{abstract}

Keywords: Amazon, esophagus, parasites, ducks, nematodes, Anisakis.

\begin{abstract}
Resumo
Entre as aves utilizadas para consumo humano, o pato doméstico está bem adaptado às várias condições climáticas. Sua criação é muito difundida devido ao seu fácil manejo. E sua carne é amplamente consumida e apreciada, principalmente na culinária do norte do Brasil. O presente estudo teve como objetivo relatar e identificar taxonomicamente os nematódeos encontrados no esôfago de patos domésticos, criados e comercializados no município de Soure, Ilha de Marajó, estado do Pará, Brasil. E também discutir o seu potencial zoonótico para o homem. As amostras consistiram em 30 espécimes de Cairina moschata domestica analisados. Um total de 258 nematódeos foram recuperados, fortemente fixados na mucosa esofágica dos hospedeiros. As características morfológicas e morfométricas foram compatíveis com as larvas de terceiro estágio de Anisakis.
\end{abstract}

Palavras-chave: Amazônia, esôfago, parasitos, patos, nematódeos, Anisakis.

\section{Introduction}

Among the avian used for human consumption, the Muscovy duck is well adapted to various climatic conditions and its breeding is widespread due to its easy handling (Béjcek \& Stastný, 2002). Muscovy duck Cairina moschata domestica is widely consumed and appreciated, mainly in the local cuisine of the state of Pará, northern Brazil 
(Almeida et al., 2014). Although they have great physical resistance, this species of duck is susceptible to different helminth infections (Gower, 1939).

Nematodes Ascaridoidea, particularly members of the Anisakidae are widely regarded as among pathogenic organisms for human health (Desowitz, 1986; Shamsi \& Suthar, 2016). In Brazil, this family of parasites is represented by 4 subfamilies: Anisakinae Railliet \& Henry, 1912; Goeziinae Travassos, 1919; Pseudanisakinae Petter, Paradiznik, Radujkovic \& Cassone, 1991 and Raphidascaridinae Hartwich, 1954 and 10 genera: Anisakis Dujardim, 1845; Contracaecum Railliet \& Henry, 1912; Pseudoterranova Railliet \& Henry, 1912; Terranova Leiper \& Atkinson, 1914; Raphidascaris Railliet \& Henry, 1915; Hysterothylacium Ward \& Magath, 1917; Pseudanisakis (Layman \& Borovkova, 1926) Yamaguti, 1941; Iheringascaris Pereira, 1935; Pulchrascaris Vicente \& Santos, 1972 and Goezia Zeder, 1800, parasitizing different species of fish (Luque et al., 2011). The infections by nematode larvae from the Anisakidae family result in a combination of two factors: direct action of larvae during tissue invasion and interactions between the host immune system and the substances released by the parasites (Ubeira et al., 2000).

In Brazil, there are several records of anisakid nematodes parasitizing fish, some of them have zoonotic potential (Fontenelle et al., 2013). In 2017, the Brazilian Ministry of Health classified the biological risk of anisakid infection as belonging to Risk Class 2, where there is moderate individual risk and limited risk to the community and for which there are known prophylactic and therapeutic measures (Brasil, 2017). Larvae of some anisakids of the genera Anisakis and Pseudoterranova, in particular, have considerable significance to public health and the economy (Smith \& Wootten, 1978; Bowen, 1990; Anderson, 2000; McClelland et al., 2000). Although there are many studies related to anisakid larvae in fish (Pinheiro et al., 2019), in avian these studies are scarce, especially when related to the life cycle of the parasites (Mattos et al., 2008). Thus, this study was to taxonomically identify the specimens of anisakid nematodes found in Muscovy duck raised in Soure, Marajó Island, through morphological and morphometric analysis and discuss its zoonotic potential to human.

\section{Materials and Methods}

Thirty specimens of $C$. moschata domestica, 19 females and 11 males (4-8 months) were acquired from rural properties in the municipality of Soure ( $\left.0.54^{\circ} 12^{\prime} 05^{\prime \prime} \mathrm{S} ; 48^{\circ} 67^{\prime} 01^{\prime \prime} 39 \mathrm{~W}\right)$, Island of Marajó, state of Pará, Brazil (Figure 1). The ducks were components of small flocks raised extensively with free access to the environment. The ducks were slaughtered on the farm by stunning with a club, cutting the blood vessels in the neck, exsanguination and

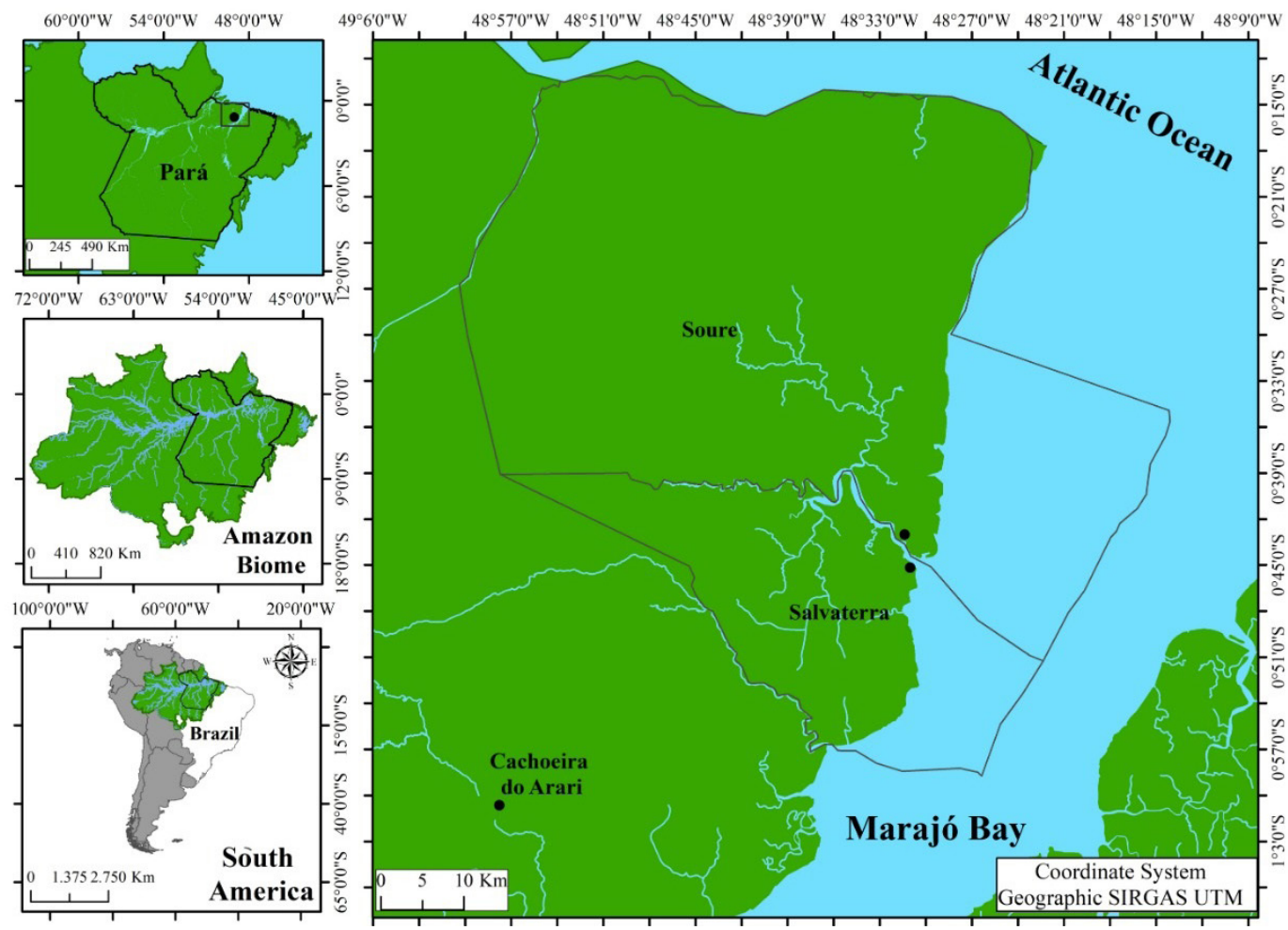

Figure 1. Collection locality of Cairina moschata domestica in municipality of Soure, Marajó Island, State of Pará, Brazil. 
only the organs of the digestive tract were transported to the laboratory for analyze. In the laboratory, the organs were separated and placed in Petri dishes with $\mathrm{NaCl} 0.9 \%$ saline solution and examined using stereomicroscopes (LEICA ES2). The nematodes were recovered dead and fixed in a solution of AFA (93 parts of 70\% ethanol, 5 parts of formaldehyde, and 2 parts of glacial acetic acid) and processed for brigthfield and scanning electron microscope (SEM) according to Pinheiro et al. (2019) method. Measurements are givens in micrometers unless otherwise noted and are presented as the mean followed by the range (minimum and maximum values) in parentheses. Taxonomic classification of nematodes was in accordance with Vicente et al. (1995b), Moravec (1998), De Ley \& Blaxter (2002), Felizardo et al. (2009), Gibbons (2010) and Fonseca et al. (2016). The ecological indexes of parasitism were used according to Bush et al. (1997) and Bautista-Hernández et al. (2015).

Deposit of specimens: Four specimens (000240MPEG), (000241MPEG), (000242MPEG) and (000243MPEG) were deposited in the Coleção de Invertebrados of the Museu Paraense Emílio Goeldi (MPEG), Belém, Pará, Brazil.

\section{Results}

In the present study, a total of 258 nematodes were recovered from the esophagus mucosa of $C$. moschata domestica, with prevalence of $10 \%$, mean intensity of 86 , mean abundance of 8.6 and range of infection of 1 to 243 nematodes per bird. All nematode specimens collected were identified as Anisakis sp. third-stage larvae, and were strongly attached in the esophageal mucosa (Figures 2a-b). Its taxonomic classification and its morphological and morphometric characteristics are presented below.
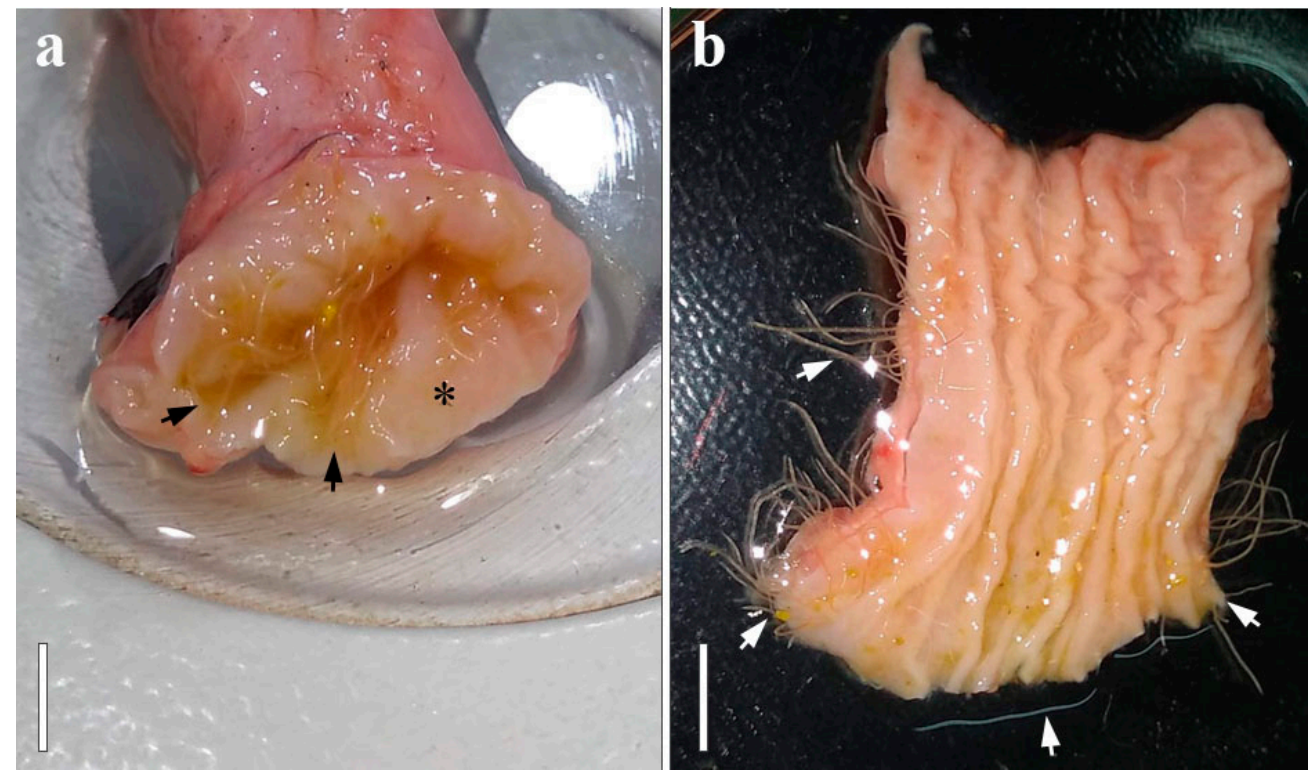

Figure 2. Figure 2. Macroscopic observation of the esophagus of Cairina moschata domestica: (a) Presence of Anisakis sp. thirdstage larvae (Arrowhead) in the early portion of the esophagus $\left({ }^{*}\right)$. Bar $=2 \mathrm{~cm}$; (b) Esophageal opening in longitudinal section, with several Anisakis sp. third-stage larvae (Arrowhead) attached to the esophageal mucosa. Bar $=2 \mathrm{~cm}$.

\section{Ascaridoidea Baird, 1853}

\section{Anisakidae Railliet \& Henry, 1912}

\section{Anisakis Dujardin, 1845}

Main features based on ten third-stage larvae observed by brigthfield and scanning electron microscope: Body, $12.09 \mathrm{~mm}$ (9.14-14.91 mm) length; width 195 (160-227). Larval tooth near oral opening oval (Figures 3a, 4a). Anterior end with three undeveloped lips and four cephalic papillae, two on the dorsal lip and one on each ventrolateral lip (Figures 4b-c). Ventral excretory pore located just below the ventrolateral lips (Figure 4c). Esophagus $1.00 \mathrm{~mm}$ $(0.70-1.00 \mathrm{~mm}$ ) length, $8.27 \%$ of total body length (Figure 3a). Rectangular ventricle, 345 (247-473) length, $89(60-127)$ width (Figure 3a). The length ratio of the esophagus and ventricle is $11.16 \%$ of the total body length. 


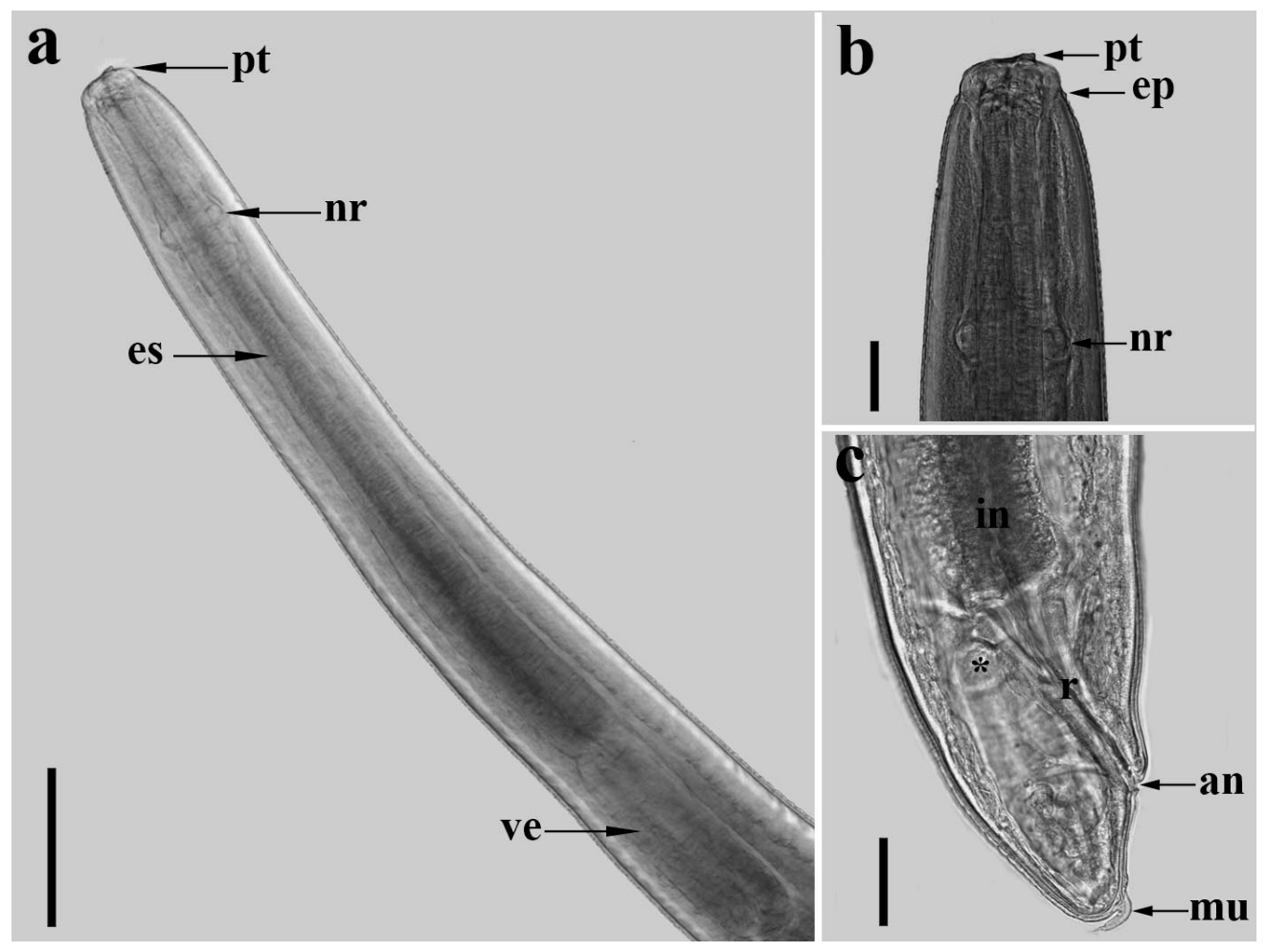

Figure 3. Light microscopy of Anisakis sp. (L3 larvae) parasite of Cairina moschata domestica: (a) Lateral view of the cephalic region showing evidence a pointed tooth (pt), nerve ring (nr), esophagus (es) and ventricle (ve). Bar = $200 \mu \mathrm{m}$; (b) Detail of pointed tooth (pt), excretory pore (ep), nerve ring (nr) and cuticle with delicate transversal striations. Bar = $50 \mu \mathrm{m}$; (c) Posterior portion showing: intestine (in), rectum (r), rectal glands (*), anus (an) and the tail with mucron (mu). Bar $=50 \mu \mathrm{m}$.

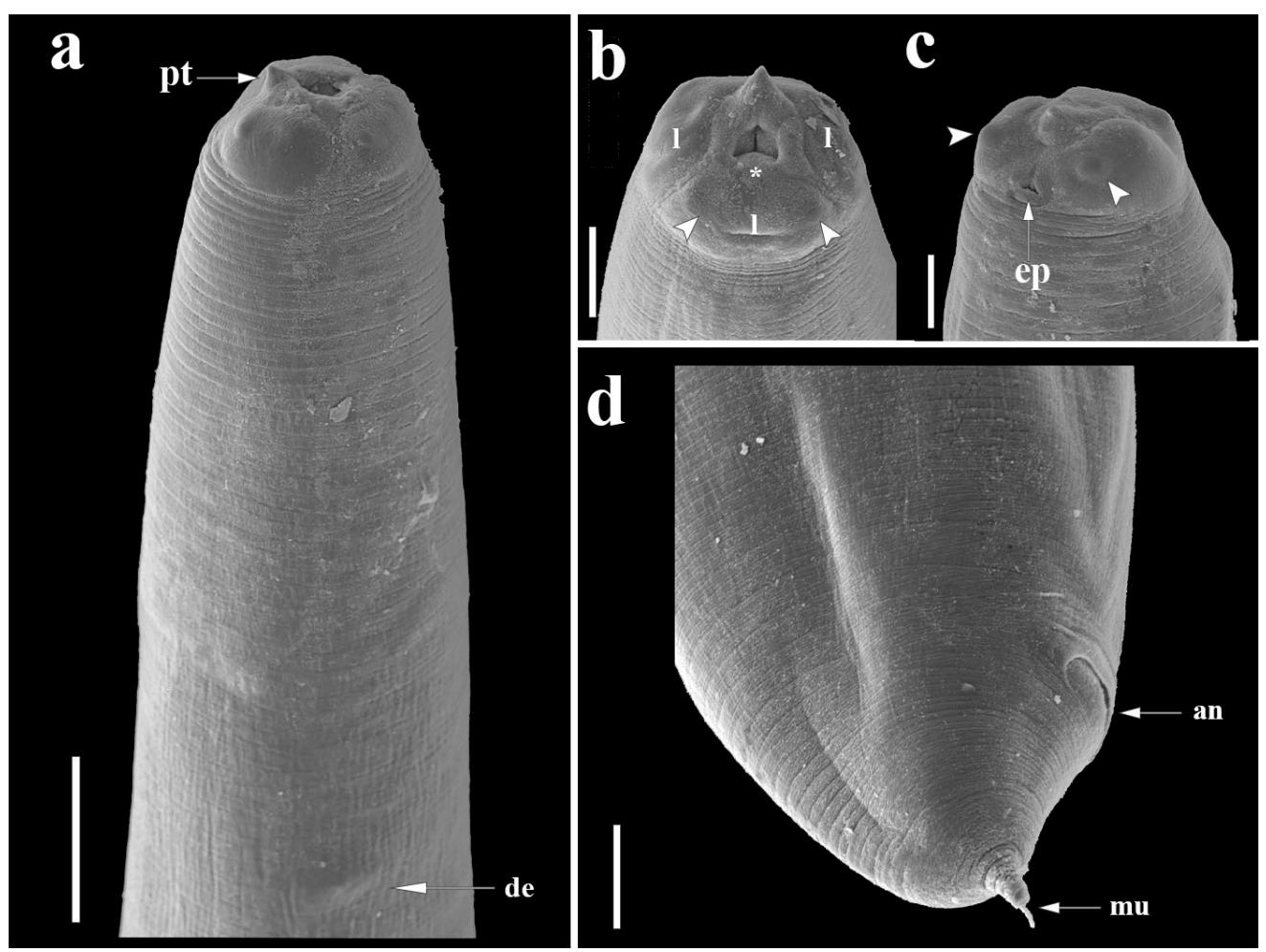

Figure 4. Photomicrography by scanning electron microscope of Anisakis sp. parasite of Cairina moschata domestica: (a) Dorso-lateral view of the cephalic region showing a pointed tooth (pt), deirid (de) and cuticle with delicate transversal striations. Bar = $50 \mu \mathrm{m}$; (b) Anterior end with three undeveloped lips (I) and four cephalic papillae, two on the dorsal lip (Arrowhead), oral opening oval (*). Bar $=20 \mu \mathrm{m}$; (c) Ventral view of excretory pore (ep) opening beneath the pointed tooth and cephalic papillae one on each ventro-lateral lip (Arrowhead). Bar = $20 \mu \mathrm{m}$. (d) Anus (an) and tail conical with mucron present (mu). Bar = $20 \mu \mathrm{m}$. 
Absent ventricular appendix and intestinal cecum. Distance from the anterior end to the nerve ring 200 (160-213) (Figures 3a-b). Three approximately spherical rectal glands (Figure 3c). Tail conical 66 (48-75), with a terminal mucron 24 (13-38) (Figures 3c, 4d).

\section{Discussion}

In the present study, the Anisakis sp. third-stage larvae (with retangular ventricle and mucron terminal) found parasitizing the esophagus of $C$. moschata domestica presented the same morphological and similar morphometrical characteristics observed in Anisakis spp. third-stage larvae reported in several Brazilian marine and brackish fish species (Timi et al., 2001; Felizardo et al., 2009; Saad, 2010; Fonseca et al., 2016; Fontenelle et al., 2016). In the species of the present study, the morphometric differences observed in the body size and its structures comparing with the Anisakis spp. third-stage op. cit. reported in Brazilian fish were considered as range of their measurements.

The present study reports the first occurrence of an Anisakidae species parasitizing Muscovy ducks in Brazil. According to Vicente et al. (1995b) the previous reports of Anisakidae parasitizing birds in Brazil were only of Contracaecum genus such as Contracaecum caballeroi Bravo-Hollis, 1939 in Falconiformes (Pinto et al., 1994); Contracaecum crenulatum Schuurmans-Stekhoven, 1937 in Pelecaniformes (Rodrigues \& Vicente, 1969); Contracaecum granulosum (Schneider, 1866) Baylis, 1932 in Suliformes (Rodrigues \& Vicente, 1969; Vicente et al., 1995a); Contracaecum microcephalum (Rudolphi, 1809) Baylis, 1920 Pelecaniformes; Contracaecum multipapillatum (Drasche, 1882) Baylis, 1920 in Ciconiiformes and Suliformes (Cram, 1927; Vicente et al., 1995a); Contracaecum pelagicum Johnston \& Mawson, 1942 in Sphenisciformes (Rodrigues \& Rodrigues, 1970); Contracaecum plagiaticium Lent \& Freitas, 1948 in Pelecaniformes and Contracaecum sp. in Pelecaniformes (Travassos, 1945; Vicente et al., 1993, 1995b).

In relation to that found by Anisakis sp. third-stage larvae that parasitize the esophageal mucosa of the Muscovy duck of Soure, in the state of Pará, in present study, special care should be taken when handling this bird for consumption by traders and consumers, as birds contaminated with these larvae infectious can cause human anisakiasis. Thus, reinforcing the importance of proper handling in removing the duck's viscera, its correct disposal, avoiding the overflow of the larvae to the duck's musculature or direct contact with the handler's skin, these birds have a relevant role in local cuisine, even if they do not. whether it is a dish served raw, it is known that these parasites can cause allergy, when ingested or by contact, even after being cooked and dead (Audicana et al., 2002).

This is the first record of Anisakis sp. third-stage larvae in Soure, parasitizing birds, focusing on the food importance of the Muscovy duck for the region. Previously reports of Anisakis species in Brazil were involved with parasitism of commercial fish in different states (Luque et al., 2011). Based on larval morphology, reported the occurrence of Anisakis physeteris (Baylis, 1923); Anisakis typical (Diesing, 1860) Baylis, 1920; Anisakis simplex (Rudolphi, 1809) and Anisakis pegreffii Campana-Rouget \& Biocca, 1955. In addition, different authors who report the occurrence of Anisakis larvae parasitizing commercial fish in different states from the Brazil. For northern Brazil, there are few reports of Anisakis larvae (see Salgado, 2010; Rodrigues et al., 2015; Fontenelle et al., 2016; Morey \& Malta, 2018), and this low occurrence may be related to the strong influence of the Amazon River system. This makes the environment predominantly freshwater, with only minor invasions of some saltwater fish species in the estuary, which may possibly maintain the parasite cycle in these environments, as the Anisakis genus needs marine mammals to complete its life cycle. Gračan et al. (2012) reported the occurrence of Anisakis larvae in loggerhead sea turtle Caretta caretta in the Adriatic Sea, and these authors characterized this genus as a generalist nematode, which infect a wide variety of hosts.

On Marajó Island, birds are bred extensively making these animals generalists in their diet. Although poultry farming is strong in the region, fishing is one of the main commercial activities of the local riverine population, with fish being eviscerated on beaches or backyards, where Muscovy ducks act as a paratenic host when ingesting these infected viscera or becoming infected by filtering the water containing parasitized microcrustaceans. Aquatic and terrestrial mammals act as definitive hosts when feeding on these birds, which could be a hypothesis for the maintenance of the possible cycle of parasitism by larvae of Anisakis sp. on the Marajó Island (Figure 5). In general, the life cycle of the Anisakidae nematodes involves different intermediate hosts, and includes four larval stages (L1-L4) and adult parasites are found in the stomach and small intestine of the definitive host (Smith \& Wootten, 1978; Yoshinaga et al., 1989; Klimpel et al., 2008, 2010). For the Anisakis and Pseudoterranova, marine mammals play the role of definitive hosts, benthic and planktonic crustaceans are intermediate hosts, and fish and cephalopods (squid) acts as paratenic hosts (Gómez Sáenz et al., 1999; Ramos, 2011). Freshwater or marine piscivorous birds have played an important role in the transmission of anisakids to aquatic mammals (Garbin et al., 2007). 


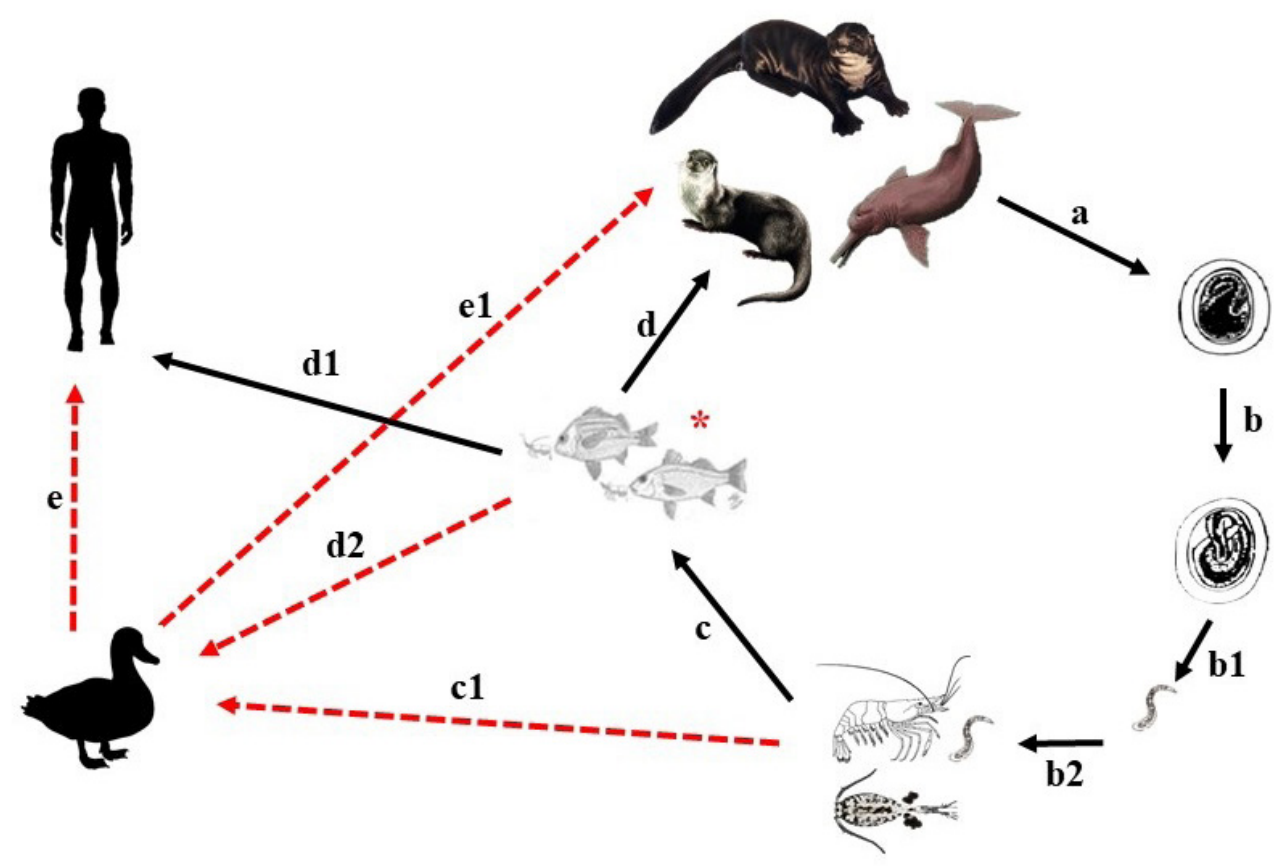

Figure 5. Cycle proposal for occurrence of Anisakis sp. Cairina moschata domestica parasite on Marajó Island, state of Pará. (a) Adult nematodes reside in the stomach and intestines of aquatic mammals and eliminate non-embryonated eggs along with feces in the water; b-b1) Eggs in contact with water become embryos and develop into first-stage larva (L1), which hatch into a second-stage larva (L2) that actively swims; b2) Larvae are ingested by crustaceans (1st Intermediate Host), where they develop into third-stage larvae (L3) (infective stage); c) When fish ingested contaminated crustaceans, they become the second intermediate host $\left({ }^{*}\right)$, the L3 migrate to the muscle tissue in which they live; d) Piscivorous aquatic mammals may act as definitive hosts, starting the cycle again; d1) Humans may act as accidental hosts, being infected by eating raw or undercooked meat from infected fish; (d2) Muscovy ducks (paratenic host) are infected by ingesting the viscera of fish infected with L3, made available by fishermen when they are cleaning the fish for consumption. e) Humans may be infected by eating raw or undercooked meat from ducks accidentally infected with L3; e1) Aquatic and terrestrial mammals act as definitive hosts when they feed on these birds, which could be a hypothesis to maintain the Anisakis cycle on the island.

In the present study, no adults of Anisakis were found parasitizing Muscovy duck on Marajó Island, only L3 larvae. Mattiucci et al. $(2002,2005)$ stated that larval stages of the Anisakidae have no host specificity and can be found in a wide variety of fish species. Because it is an environment with an immense fish biodiversity, the island of Marajó is based on using fish as a major food source, thus increasing the likelihood of transmission of the parasites to the ducks raised on the island, reinforcing the hypothesis that ducks erratically enter the cycle of this parasite when ingesting fish offal. According to the aforementioned authors, L3 larvae pierce the intestinal wall and remain free in the abdominal cavity or migrate to the viscera or muscle of the fish, where they encyst, conserving their capacity for infection, which is an alert for the population that uses Muscovy ducks as food.

Although the prevalence (10\%) was low in this study, it still provides an alert of the possible zoonotic potential of this occurrence in Muscovy ducks. The first case of human anisakiasis was recorded in 1960, and nearly 13,000 cases were diagnosed between 1968 and 1989 in Japan, where anisakiasis is considered a public health problem (Van Thiel et al., 1960; Ishikura, 1989). Pereira et al. (2000) believed that due to the growing popularity of Brazilian restaurants and fast-food establishments specializing in Japanese food, it would be possible to observe the first cases of anisakiasis in Brazil. Cruz et al. (2010) reported the first case of this disease in humans by endoscopy of the gastrointestinal tract, the authors suggested possible contamination through ingestion of raw or undercooked fish meat.

The richness and diversity of members of the anisakids, their hosts and life cycle are not well established in Brazil. Previously reports of anisakids in the same biogeographic region were related to occurrence of Contracaecum sp. in Astronotus ocellatus, a commercial important fish for the Amazon region., where the occurrence of Contracaecum was also related to 16 orders, 49 families, 96 genera, 140 species and the "Patinga" hybrid morphotype, which is the result of interspecific hybridization between a female (F1) of Piaractus mesopotamicus and male (M1) of Piaractus brachypomus, all distributed in three aquatic habitats (Pinheiro et al., 2019). Although for Contracaecum 
the definitive hosts are piscivorous birds and for Anisakis they are aquatic mammals, fish are important because they act directly in the cycle. According to McCarthy \& Moore (2000) an alternative explanation has been proposed to explain the increased presence of anisakid third-stage larvae in fish, which may be related to the decrease of definitive hosts (marine mammals: dolphins, whales, seals and sea lions), especially after the regulation of hunting of these animals in different countries, resulting in the concomitant increase in the level of fish contamination.

\section{Conclusions}

In the present study, Anisakis sp. third-stage larvae that parasitize the Muscovy duck and the bird are related as one of the paratenic hosts of this nematode. The zoonotic potential of these parasites must be considered, given the need for greater sanitary control in the consumption of these birds. Only third-stage larvae were found, because the duck acts as a paratenic host. However, this host act as a paratenic host can only happen if these ducks were ingested by some local predator. As an important fact the present study generates information for the parasitic fauna of $C$. moschata domestica in Brazil and alerts the population of Marajó, who uses these birds as food. Although the lining of the esophagus is not an edible part of the duck, it is known that this nematode causes anisakiasis; therefore, the population must be alerted by health surveillance to the risks of acquiring an infection and how to proceed to avoid it.

\section{Acknowledgements}

The authors are grateful the Laboratório de Microscopia Eletrônica de Varredura - ISPA - UFRA, campus Belém, state of Pará, Brazil for the use of the scanning electron microscope. This study is part of the dissertation of Elaine Lopes de Carvalho, developed for the Programa de Pós-Graduação Saúde e Produção Animal na Amazônia, Instituto da Saúde e Produção Animal, Universidade Federal Rural da Amazônia (UFRA). This study was financed in part by the Coordenação de Aperfeiçoamento de Pessoal de Nível Superior (CAPES - BRASIL) - Finance Code 001 and Ministério da Educação do Brasil. Raul Henrique da Silva Pinheiro was supported by a research fellowship from the "Universidade Federal do Oeste do Pará (UFOPA) - CAPES, BRASIL".

\section{References}

Almeida ECJ, Bittencourt TCBSC, Carneiro PLS, Gois FD, Pereira AHR, Farias RV, et al. Dimorfismo sexual do pato doméstico (Cairina moschata) utilizando análise multivariada. Actas Iberoam Conserv Anim 2014; 4(1): 53-55.

Anderson RC. Nematode parasites of vertebrates: their development and transmission. Wallingford, Oxon UK: Cabi International; 2000. http://dx.doi.org/10.1079/9780851994215.0000.

Audicana MT, Ansotegui IJ, Corres LF, Kennedy MW. Anisakis simplex: dangerous - dead and alive? Trends Parasitol 2002; 18(1): 20-25. http://dx.doi.org/10.1016/S1471-4922(01)02152-3. PMid:11850010.

Bautista-Hernández CE, Monks S, Pulido-Flores G, Rodríguez-Ibarra AE. Revisión bibliográfica de algunos términos ecológicos usados en parasitología, y su aplicación en estudios de caso. Estud Biodivers 2015; 2: 11-19.

Béjcek V, Stastný K. Enciclopédia das aves: as várias espécies e seus habitats. Lisboa: Livros; 2002.

Bowen WD. Population biology of sealworm (Pseudoterranova decipiens) in relation to its intermediate and seal hosts. Canada: Canadian Government Publishing; 1990. p. 222. Canadian Bulletin of Fisheries \& Aquatic Sciences.

Brasil. Ministério da Saúde. Classificação de risco dos agentes biológicos [online]. Brasília: Ministério da Saúde; 2017 [cited 2019 July 28]. Available from: http://bvsms.saude.gov.br/bvs/publicacoes/classificacao_risco_agentes_biologicos_3ed.pdf

Bush AO, Lafferty KD, Lotz JM, Shostak AW. Parasitology meets ecology on its own terms: margolis et al. revisited. J Parasitol 1997; 83(4): 575-583. http://dx.doi.org/10.2307/3284227. PMid:9267395.

Cram EB. Bird parasites of the nematode suborders Strongylata, Ascaridata, and Spirurata. Bull United States Nat Mus 1927; 140(140): 1-465. http://dx.doi.org/10.5479/si.03629236.140.1.

Cruz AR, Souto PCS, Ferrari CKB, Allegretti SM, Arrais-Silva WW. Endoscopic imaging of the first clinical case of Anisakidosis In Brazil. Rev Sci Parasitol 2010; 11(2): 97-100.

De Ley P, Blaxter ML. Systematic position and phylogeny. In: Lee DL. The biology of nematodes. London: Taylor and Francis; 2002. p. 1-30. http://dx.doi.org/10.1201/b12614-2. 
Desowitz RS. Human and experimental anisakiasis in the United States. Hokkaido Igaku Zasshi 1986; 61(3): 358-371. PMid:3527918.

Felizardo NN, Knoff M, Pinto RM, Gomes DC. Larval anisakid nematodes of the flounder Paralichthys isosceles Jordan, 1890 (Piscei:Teleostei) from Brazil. Neotrop Helminthol 2009; 3(2): 57-64.

Fonseca MCG, Knoff M, Felizardo NN, Di Azevedo MIN, Torres EJL, Gomes DC, et al. Integrative taxonomy of Anisakidae and Raphidascarididae (Nematoda) in Paralichthys patagonicus and Xystreurys rasile (Pisces: Teleostei) from Brazil. Int J Food Microbiol 2016; 235: 113-124. http://dx.doi.org/10.1016/j.ijfoodmicro.2016.07.026. PMid:27491056.

Fontenelle G, Knoff M, Felizardo NN, Lopes LMS, São Clemente SC. Nematodes of zoonotic importance in Cynoscion guatucupa (Pisces) in the state of Rio de Janeiro. Rev Bras Parasitol Vet 2013; 22(2): 281-284. http://dx.doi.org/10.1590/S198429612013005000019. PMid:23778824.

Fontenelle G, Knoff M, Felizardo NN, Torres EJL, Matos ER, Gomes DC, et al. Anisakid larva parasitizing Plagioscion squamosissimus in Marajó Bay and Tapajós River, state of Pará, Brazil. Rev Bras Parasitol Vet 2016; 25(4): 492-496. http://dx.doi.org/10.1590/ s1984-29612016034. PMid:28001171.

Garbin LE, Navone GT, Diaz JI, Cremonte F. Further study of Contracaecum pelagicum (Nematoda: Anisakidae) in Spheniscus magellanicus (Aves: Spheniscidae) from Argentinean coasts.J Parasito/ 2007; 93(1): 143-150. http://dx.doi.org/10.1645/GE-875R1.1. PMid:17436954.

Gibbons LM. Keys to the nematode parasites of vertebrates: supplementary volume. Oxon, Wallingford, UK: Cabi Publishing; 2010.

Gómez Sáenz JT, Gérez Callejas MJ, Zangróniz Uruñuela MR, Muro Ovejas E, González JJ, García Palacios MJ. Reacciones de hipersensibilidad y manifestaciones digestivas producidas por la ingestión de pescado parasitado por Anisakis simplex. Semergen 1999; 25(9): 792-797.

Gower WC. Host-parasite catalogue of the helminths of ducks. Am Midl Nat 1939; 22(3): 580-628. http://dx.doi.org/10.2307/2420338.

Gračan R, Buršić M, Mladineo I, Kučinić M, Lazar B, Lacković G. Gastrointestinal helminth community of loggerhead sea turtle Caretta caretta in the Adriatic Sea. Dis Aquat Organ 2012; 99(3): 227-236. http://dx.doi.org/10.3354/dao02490. PMid:22832721.

Ishikura H. General survey of Anisakis and Anisakiasis in Japan. In: Ishikura H, Namiki M, editors. Gastric anisakiasis in Japan. Tokyo: Springer; 1989. p. 3-11. http://dx.doi.org/10.1007/978-4-431-68290-5_2

Klimpel S, Busch MW, Kuhn T, Rohde A, Palm HW. The Anisakis simplex complex off the South Shetland Islands (Antarctica): endemic populations versus introduction through migratory hosts. Mar Ecol Prog Ser 2010; 403: 1-11. http://dx.doi.org/10.3354/meps08501.

Klimpel S, Kellermanns E, Palm HW. The role of pelagic swarm fish (Myctophidae: Teleostei) in the oceanic life cycle of Anisakis sibling species at the Mid-Atlantic Ridge, Central Atlantic. Parasitol Res 2008; 104(1): 43-53. http://dx.doi.org/10.1007/s00436008-1157-3. PMid:18758825.

Luque JL, Aguiar JC, Vieira FM, Gibson DI, Santos CP. Checklist of Nematoda associated with the fishes of Brazil. Zootaxa 2011; 3082(1): 1-88. http://dx.doi.org/10.11646/zootaxa.3082.1.1.

Mattiucci S, Nascetti G, Dailey M, Webb SC, Barros NB, Cianchi R, et al. Evidence for a new species of Anisakis Dujardin, 1845: morphological description and genetic relationships between congeners (Nematoda: Anisakidae). Syst Parasitol 2005; 61(3): 157-171. http://dx.doi.org/10.1007/s11230-005-3158-2. PMid:16025205.

Mattiucci S, Paggi L, Nascetti G, Portes Santos C, Costa G, Di Beneditto AP, et al. Genetic markers in the study of Anisakis typica (Diesing, 1860): larval identification and genetic relationships with other species of Anisakis Dujardin, 1845 (Nematoda: Anisakidae). Syst Parasitol 2002; 51(3): 159-170. http://dx.doi.org/10.1023/A:1014554900808. PMid:11912342.

Mattos DG Jr, Costa DA, Menezes RC, Mesquita EM. Prevalence of helmintos in domestic ducks Cairina moschata dom. (Linné) (Anseriformes, Anatidae, Cairinini, Cairina) proceeding from extensive creations in the state of Rio de Janeiro, Brazil. $\mathrm{R} B \mathrm{Bras} \mathrm{Ci}$ Vet 2008; 15(3): 140-142. http://dx.doi.org/10.4322/rbcv.2014.215.

Mccarthy J, Moore TA. Emerging helminth zoonoses. Int J Parasito/ 2000; 30(12-13): 1351-1359. http://dx.doi.org/10.1016/S00207519(00)00122-3. PMid:11113260.

McClelland G, Misra RK, Martell DJ. Spatial and temporal distributions of larval sealworm (Pseudoterranova decipiens, Nematoda: Anisakinae), in Hippoglossoides platessoides (Pleuronectidae) in eastern Canada from 1980 to 1990. ICES J Mar Sci 2000; 57(1): 69-88. http://dx.doi.org/10.1006/jmsc.1999.0518.

Moravec F. Nematodes of freshwater fishes of the Neotropical Region. Praha: Academia, Publishing House of the Academy of Sciences of the Czech Republic; 1998.

Morey GAM, Malta JCO. Metazoan parasites of Acestrorhynchus falcatus (Characiformes: Acestrorhynchidae) from floodplain lakes of the Brazilian Amazon. Neotrop Helminthol 2018; 12(2): 147-152.

Pereira AD, Atui MB, Torres DMAGV, Mangini AC, Zamboni CQ. Incidência de parasitos da família Anisakidae em bacalhau (Gadus morhua) comercializado no Estado de São Paulo. Rev Inst Adolfo Lutz 2000; 59(1-2): 45-49. 
Pinheiro RHS, Furtado AP, Santos JN, Giese EG. Contracaecum larvae: morphological and morphometric retrospective analysis, biogeography and zoonotic risk in the amazon. Rev Bras Parasitol Vet 2019; 28(1): 12-32. http://dx.doi.org/10.1590/s198429612019002. PMid:30892463.

Pinto RM, Vicente JJ, Noronha D. Nematode parasites of Brazilian accipitrid and falconid bird (Falconiformes). Mem Inst Oswaldo Cruz 1994; 89(3): 359-362. http://dx.doi.org/10.1590/S0074-02761994000300010.

Ramos P. Anisakis spp. em bacalhau, sushi e sashimi: risco de infecção parasitária e Alergia. Rev Port Ciênc Vet 2011; 106(577580): 87-97.

Rodrigues HO, Rodrigues SS. Redescrição de Thelazia anolabiata (Molin, 1860) (Nematoda, Spiruroidea). Atas Soc Biol 1970; 12(Suppl): 29-31.

Rodrigues HO, Vicente JJ. Redescrição de "Thelazia digitata" Travassos, 1918. (Nematoda, Spiruroidea). Atas Soc Biol 1969; 12(56): 295-297.

Rodrigues MV, Pantoja JCF, Guimarães CDO, Benigno RNM, Palha MDC, Biondi GF. Prevalence for nematoides of hygiene-sanitary importance in fish from Colares Island and Vigia, Pará, Brasil. R Bras Ci Vet 2015; 22(2): 124-128. http://dx.doi.org/10.4322/ rbcv.2015.364.

Saad CDR. Diagnóstico morfológico das larvas de Anisakidae (Nematoda: Ascaridoidea) parasitas de três espécies de peixes do litoral do estado do Rio de Janeiro, Brasil [dissertação]. Rio de Janeiro: Universidade Federal Rural do Rio de Janeiro; 2010.

Salgado RL. Avaliação parasitológica do pescado fresco comercializado no sudeste do Pará [tese]. Rio de Janeiro: Universidade Federal Fluminense; 2010.

Shamsi S, Suthar J. A revised method of examining fish for infection with zoonotic nematode larvae. Int J Food Microbio/ 2016; 227: 13-16. http://dx.doi.org/10.1016/j.ijfoodmicro.2016.03.023. PMid:27043384.

Smith JW, Wootten R. Anisakis and anisakiasis. Adv Parasito/ 1978; 16: 93-163. http://dx.doi.org/10.1016/S0065-308X(08)60573-4. PMid:364959.

Timi JT, Sardella NH, Navone GT. Parasitic nematodes of Engraulis anchoita Hubbs et Marini, 1935 (Pisces, Engraulidae) off the Argentine and Uruguayan coasts, South West Atlantic. Acta Parasitol 2001; 46(3): 186-193.

Travassos L. Heterakis fariai Travassos, 1913 (Nematoda, Subuluroidea). Mem Inst Oswaldo Cruz 1945; 42(3): 551-557. http:// dx.doi.org/10.1590/S0074-02761945000300003. PMid:20983866.

Ubeira FM, Valiñas B, Lorenzo S, Iglesias R, Figueiras A, García-Villaescusa R. Anisaquiosis y alergia: un estúdio seroepidemiológico en la comunidad autónoma Gallega. Gallega: Consellería de Sanidade e Servicios Sociais; 2000. Documentos técnicos de salud pública.

Van Thiel PH, Kuipers FC, Roskam RT. A nematode parasitic to herring, causing acute abdominal syndromes in man. Trop Geogr Med 1960; 12(2): 97-113. PMid:13776308.

Vicente JJ, Pinto RM, Noronha D. Remarks on six species of Heterakid nematoides parasites of Brazilian tinamid birds with a description of a new species. Mem Inst Oswaldo Cruz 1993; 88(2): 271-278. http://dx.doi.org/10.1590/S0074-02761993000200015.

Vicente JJ, Pinto RM, Noronha D, Gonçalves L. Nematode parasites of Brazilian Ciconiiformes birds: a general survey with new records for the species. Mem Inst Oswaldo Cruz 1995a; 90(3): 389-393. http://dx.doi.org/10.1590/S0074-02761995000300014</jrn>.

Vicente JJ, Rodrigues HD, Gomes DC, Pinto RM. Nematóides do Brasil. Parte IV. Nematóides de Aves. Rev Bras Zoo/ 1995b; 12(Suppl 1): 1-273. http://dx.doi.org/10.1590/S0101-81751995000500001.

Yoshinaga T, Ogawa K, Wakabayashi H. Life cycle of Histerothylacium haze (Nematoda: Anisakidae: Raphidascaridinae). J Parasitol 1989; 75(5): 756-763. http://dx.doi.org/10.2307/3283061. PMid:2795378. 